\title{
Beitrag zum Winter
}

Ich wohne diesen

Winter in Neusibirien

Ganz ungewollt

Melancholisch grüsst

Die Sonne durch den Nebel

Aber sie ist da.

Die Tannen lassen

Ihre Äste schlaff hängen

Das ist sehr nachfühlbar

Auf der Schaukel sitzt

Jetzt der Schnee, der gar nicht dort

Hingehört. Amen.

Dr. med. Hedi Meierhans

he.meierhans[at]bluewin.ch

Bildnachweis

() Hedi Meierhans
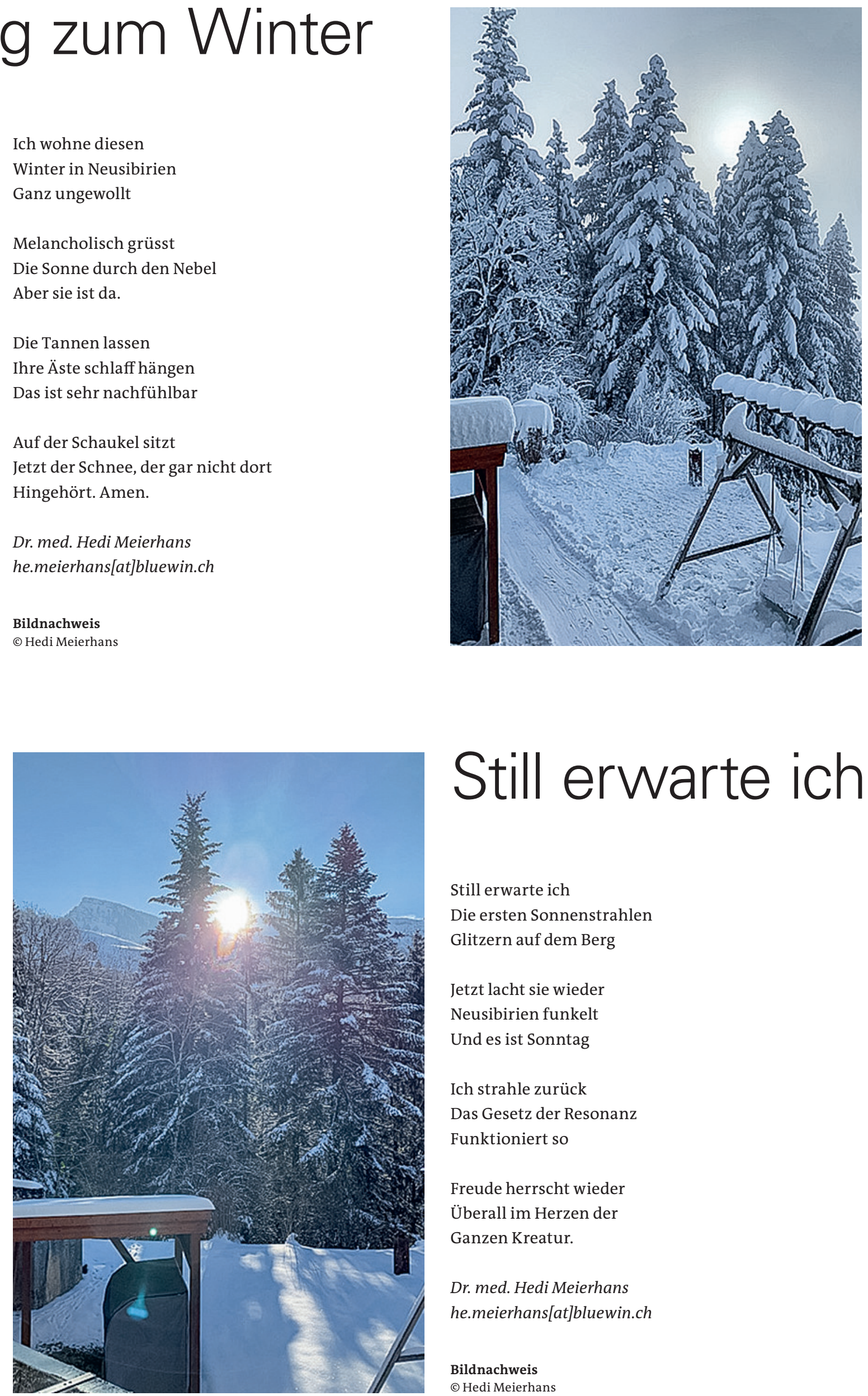

\section{Still erwarte ich}

Still erwarte ich

Die ersten Sonnenstrahlen

Glitzern auf dem Berg

Jetzt lacht sie wieder

Neusibirien funkelt

Und es ist Sonntag

Ich strahle zurück

Das Gesetz der Resonanz

Funktioniert so

Freude herrscht wieder

Überall im Herzen der

Ganzen Kreatur.

Dr. med. Hedi Meierhans

he.meierhans[at]bluewin.ch

Bildnachweis

(๑) Hedi Meierhans 